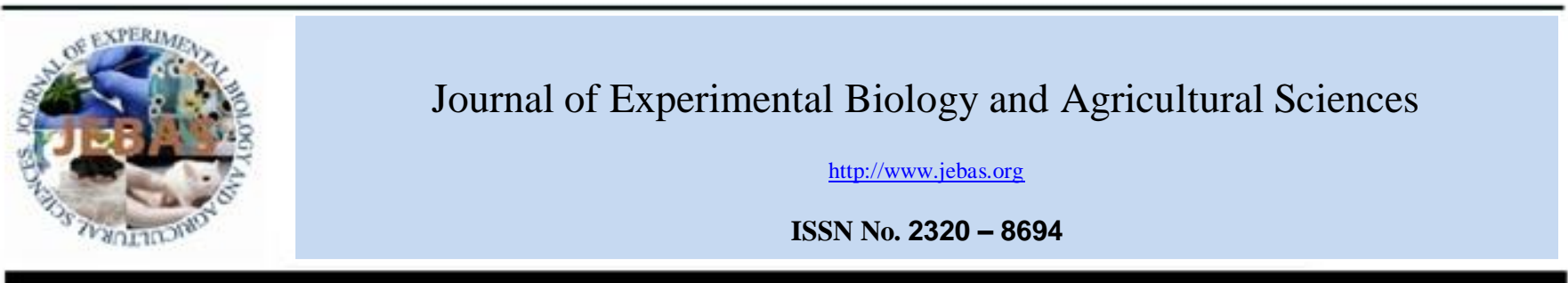

\title{
PHYTOCHEMICAL CHARACTERIZATION OF Spondias SP AND Spondias tuberosa ARRUDA CÂMERA EXTRACTS OF OCCURRENCE IN PARAIBA SEMIARID
}

\author{
Ednaldo Queiroga de Lima ${ }^{*}$, Carla Fernanda da Silva Leite Ferreira ${ }^{2}$, Elisabeth de Oliveira ${ }^{3}$, \\ Vicente Carlos de Oliveira Costa ${ }^{4}$, Maysa Kevia Linhares Dantas ${ }^{5}$
}

${ }^{1}$ Ednaldo Queiroga de Lima -Professor Post Doctor at Federal University of Campina Grande
${ }^{2}$ Carla Fernanda da Silva Ferreira - Master in Agricultural Science at Federal University of Campina Grande
${ }^{3}$ Elisabeth de Oliveira - Doctor Professor at Federal University of Campina Grande
${ }^{4}$ Vicente Carlos de Oliveira Costa - Doctor Professor at Federal University of Paraiba
${ }^{5}$ Maysa Kevia Linhares Dantas - Graduate Student of Agricutural Science at Federal University of Campina Grande

Received - September 02, 2017; Revision - October 24, 2017; Accepted - October 29, 2017

Available Online - October 31, 2017

http://dx.doi.org/10.18006/2017.5(5).713.717

\section{KEYWORDS}

Spondias

Secondary metabolites

Drugs

Bioactive compounds

\begin{abstract}
Present study was aimed to characterize the phytochemical profile of the leaf extracts of Spondias $s p$ and Spondias tuberose. During study total five trees of Spondias sp (Cajarana do sertão) and Spondias tuberosa (Umbu) with good phytosanitary was used for phytochemical analysis. From these selected trees total $5 \mathrm{~kg}$ leaves per tree were collected and air dried at $40^{\circ} \mathrm{C}$. These leaves samples were ground and pulverized; from this $200 \mathrm{~g}$ of powder sample were used to prepare ethanolic crude extract and phytochemical analysis was performed at the Laboratory of Pharmaceutical Technology, Federal University of Paraíba. The phytochemical screening was carried out by preliminary scouting method for identify the presence of alkaloids, steroids, tannins, flavonoids, terpenoids, and saponins. Results of study revealed that the presence of steroids, tannins, flavonoids and terpenoids from the leaf extracts of Spondias sp and Spondias tuberosa, these phytochemicals are important constitute of herbal medicines and pharmaceutical industry and worked as antioxidant, anti-infective, anti-allergic and anti inflammatory agents.
\end{abstract}

* Corresponding author

E-mail: equeiroga.lima @gmail.com (Ednaldo Queiroga de Lima)

Peer review under responsibility of Journal of Experimental Biology and Agricultural Sciences.

Production and Hosting by Horizon Publisher India [HPI] (http://www.horizonpublisherindia.in/).

All rights reserved.
All the article published by Journal of Experimental Biology and Agricultural Sciences is licensed under a Creative Commons Attribution-NonCommercial 4.0 International License Based on a work at www.jebas.org.

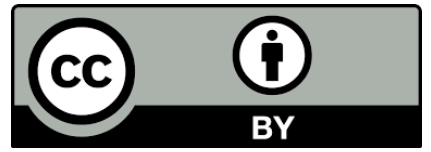




\section{Introduction}

Fruit and vegetables extract have various active ingredient and substances which are responsible for applicability in food and health. This has been stimulating the development of the study on many plants within the scope of organic chemistry in order to predict the structure and chemistry of these compounds is extremely broad and diverse (Silva et al., 2014). The phytochemical researches allow researchers to estimate the chemical constituents of the plant species or valuing their presence in various plant species (Matos, 1997; Silva et al., 2007).

The use of medicinal plants in the Northeast Brazilian population is the result of their historical heritage. They have great potential in identification, utilization, and commercialization of biologically active natural products, and have great diversity in the structure and physicochemical properties. Approximately $75 \%$ of the 121 most commonly used Brazilian drugs are derived from empirical knowledge.

The caatinga biome is very rich in medicinal plants diversity, due to their morphological characteristics, such as xilopódes and shells that accumulate reserves; they are also possessed of pharmacologically active substances. The Northeastern floras have vast biodiversity of medicinal plants which did not existing elsewhere in the world and have great pharmaceutical potential. Most communities in this region live in precarious socioeconomic situations, so there is an incentive for the use of medicinal plants.

The family Anacardiaceae has valuable pharmacological importance, where $25 \%$ of the genera of this family are known as severe contact dermatitis-causing. Species of this family became very important in search of bioactive substances. The most widely studied members of this family are Spondias, Lannea, Semecarpus, Schinus, Pistacia, Lithraea, Tapirira and Melanorrhea (Correia et al., 2006).

The Spondias are the most fruitful trees which group several important fruit species, such as cajarana do sertão (Spondias $s p$ ), umbu (Spondias tuberosa) cashew (Anacardium occidentale L.), mango (Mangifera indica L.) and pistachio (Pistacia vera L.), which are economically exploited in many tropical and subtropical areas of the world (Asuquo et al., 2013). They contain various groups of chemicals such as tannins, terpenoids (sesquiterpenes and monoterpenes), flavonoids and some of these are already detected and isolated (Dantas et al., 2014).

The main groups of compounds having pharmaceutical properties derived from plants include terpenoids, alkaloids, lectins, polypeptides, phenolic substances and polyphenols (simple phenols, phenolic acids, quinones, flavones, flavonols, and flavanols), tannins and coumarins (Haida et al., 2007).

Researches on Spondias species are in scarcity and there are gaps related to scientific knowledge of bioactive compounds produced by these species in this biome. Impacting in a Brazilian reality where, although it has the greatest plant diversity of the world and many medicinal plants are broad popular knowledge, the amount of information on these plants has grown little now (Corrêa \& Salgado, 2011).

This aims of this study was to determine the presence of secondary metabolites with pharmacological active ingredients in crude extract of Spondias sp (Cajarana do Sertão) and Spondias tuberosa Arruda Camera (Umbu) species presenting a new alternative to the research of new drugs, through natural sources, mainly presenting as a source of medicines for the low-income population.

\section{Material and Methods}

Present study was carried out in Paraíba central semiarid region. Samples of Spondias sp (Cajarana do Sertão) (Figure 1A) were collected from the rural area of municipality Santa Terezinha, Paraíba, Brazil, in the farm Lajedo while the sample of Spondias tuberosa Arruda Câmara (Umbu) (Figure 1B) were collected from the rural areas of the municipality of Matureia- PB in the farm Santo Antonio. Various plant parts such as leaves, flowers and fruits are collected for making herbarium specimens for their identification, by using the usual techniques for herborization recommended by Forman \& Bridson (1989), and recorded in the Brahms program, being deposited in the Herbarium of the Caatinga of the Health and Rural Technology Center (CSTR) at the Federal University of Campina Grande (UFCG) under the number 494 and 495 respectively. Morphological analysis for the identification, descriptions of species were carried out as according to Mobot (2012) and Forzza (2012).

Further, $5 \mathrm{Kg}$ of leaves per tree were collected and transported to the STPF/UAEF/CSTR Campus of Patos-PB of the UFCG for extracts preparation. The collected samples were air dried in an oven with circulating air at $40^{\circ} \mathrm{C}$, it was followed by the grinding these leaves in a Wiley mill and pulverized, resulting in $3.0 \mathrm{Kg}$ per species powder were obtained. Obtained powder mixed with $96 \%$ EtOH for 72 hours and repeated in every three days to obtain approximately $200 \mathrm{~g}$ of crude ethanolic extract per species. Then this material was filtered and concentrated on rota-evaporator to yield approximately $80 \mathrm{~g}$ per species.

The phytochemical analyses were performed in the Laboratory of Pharmaceutical Technology (LTF), of the Federal University of 


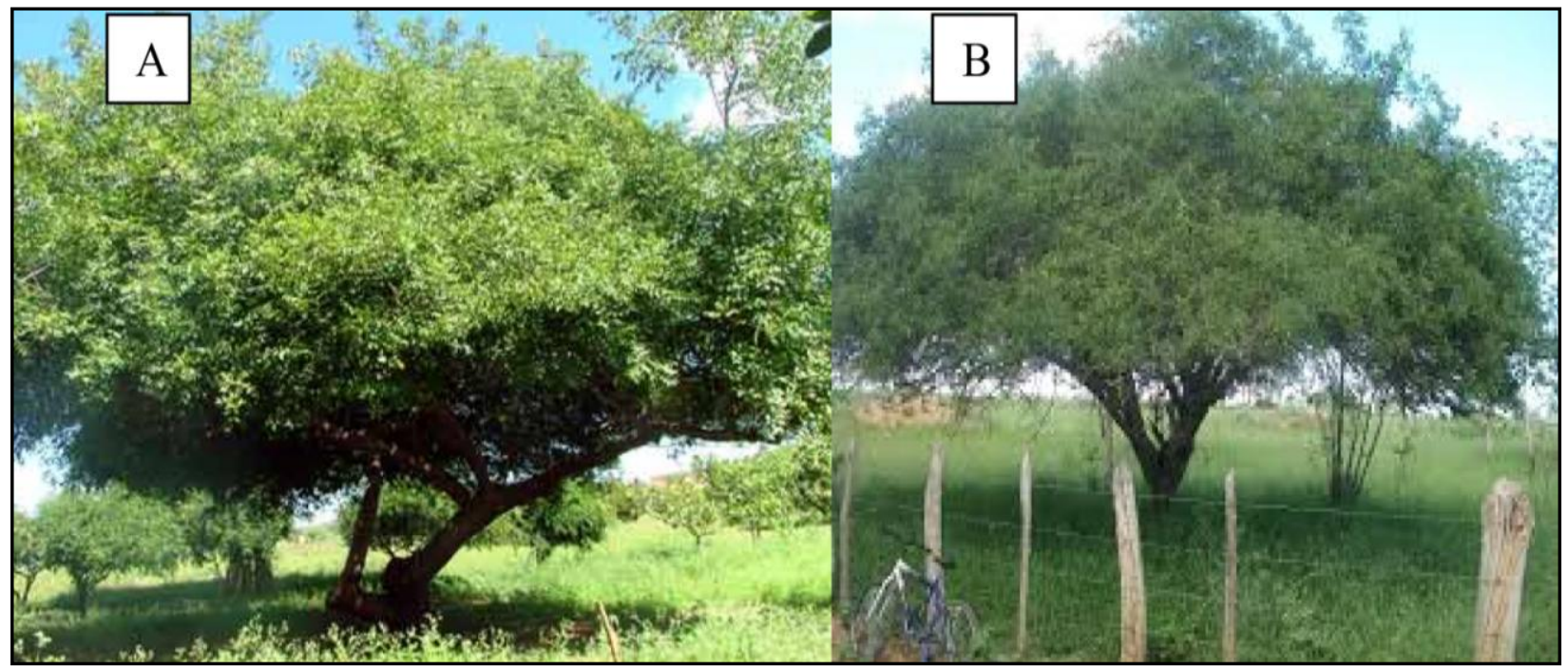

Figure 1 Sample of the selected species (a) Spondias sp. (Cajarana do sertão) and (b) Spondias tuberosa Arruda. Câmara (Umbu)

Paraíba (UFPB) by preliminary scouting technique, by the preliminary scouting method.

Hydroalcoholic extract were used for the identification of available phytochemicals such as heterosides saponosides (determination of foam), tannins (reaction with gelatin and ferric chloride), heterosides flavonics/terpenoids (magnesium ribbon and fluorescence), steroids (reaction Liebermann- Burchard), alkaloids (reactions Reactive: Dragendorff, Mayer, Burchard and silico tungstic acid) according to Matos (1997) and Costa (2000).

\section{Results and Discussion}

Preliminary phytochemical screening of secondary metabolites present in the leaf extracts of Spondias $s p$ and Spondias tuberosa Arruda Câmara have been presented in Table 1. Results of study verify the presence of steroids, tannins, flavonoids, terpenoids and the absence of alkaloids and saponins. A positive correlation was reported in the formation of precipitates and the appearance of color and foam; accordingly available phytochemicals are classified as weakly positive, moderate positive, positive and strong positive.

In relation to steroidal compounds, the results were positive, as compared with the crude extract, was noted the appearance of a green or blue coloration after Liebrman-Burchard reaction. Steroids are actively involved in the development and control of the human reproductive system, functioning as cardiotonic, vitamin D precursors, anti-inflammatory agents and anabolic agents, analgesics.
Similarly, the tests conducted for the presence of tannins were found positive by forming a green or blue coloration and also by precipitate formation. This secondary metabolite has vast therapeutic applications such as prevention of lipids peroxidation and nucleotide degradation; it also accelerates the healing process (Macedo et al., 2007).

For finding out the presence of flavonoids, the conducted tests were showing color ranging from pink to a deep red. Several biological activities such as antioxidant, antiinflammatory and anticancer activities are associated with the flavonoids (Verdi et al, 2005)

The fluorescence UV reactivity indicated the presence of terpenoids. This metabolite is of therapeutic interest, constitute a large group of chemical substances biosynthesized extracted from natural products. Terpenoids have several well defined biological activities including antifungal, anti-inflammatory and analgesic (Silva et al., 2007).

The reactive Bouchardat, Mayer, Dragendorff, and Bertrand presented negative result as in the alkaloids identification, by lack of precipitate formation floculose or clouding of the solution. Similarly, the test conducted for saponins were also found negative in the absence of permanent foam or the collar after the solution was stirred.

Several authors who have worked on various Spondias species such as Caja (Spondias mombin) Umbu (Spondias tuberosa Arr Cam.), Spondias pinnata, umbu-cajazeira (Spondias sp), and with other Anacardeacea as Aroeirra (Myracrodruon urundeuva) also 
Table 1 Phytochemical screening by preliminary scouting in species Spondias sp. and Spondias tuberosa Arruda Câmara

\begin{tabular}{|c|c|c|c|}
\hline Chemical Group & Method for Identification & Spondias sp & Spondias tuberosa \\
\hline \multirow{4}{*}{ ALKALOIDS } & Bouchardat & - & - \\
\hline & Mayer & - & - \\
\hline & Dragendorff & - & - \\
\hline & Acid silico-tungstic & - & - \\
\hline \multirow{3}{*}{ STEROIDS } & Reagent 0.12 & + & + \\
\hline & Reagent 0.25 & + & + \\
\hline & Reagent 0.50 & +++ & ++ \\
\hline \multirow{6}{*}{ TANNINS } & Gelatin $0.5 \%-0.5$ & + & + \\
\hline & Gelatin $0.5 \%-1.0$ & + & + \\
\hline & Gelatin $0.5 \%-2.0$ & ++ & ++ \\
\hline & $\mathrm{FeCl}_{3} 2.0 \%-0.5$ & ++ & ++ \\
\hline & $\mathrm{FeCl}_{3} 2.0 \%-1.0$ & ++ & ++ \\
\hline & $\mathrm{FeCl}_{3} 2.0 \%-2.0$ & ++ & ++ \\
\hline FLAVONOIDS & TAPE - MAGNESIUM & +++ & ++ \\
\hline TERPENOIDS & FLUORESCENCE & +++ & +++ \\
\hline SAPONINS & FOAM & - & - \\
\hline
\end{tabular}

confirmed the presence of constituents reported in this study (Gupta \& Moreira, 2010; Asuquo et al., 2013; Dantas et al., 2014 ).

Some species of Anacardiaceae which are of the same family as Spondias, Mangifera indica (common mango) and Anacardium ocidentale L. (cashew), did not have some of these chemicals such as tannins, flavonoids, and steroids (Correia et al., 2006; Silva et al., 2007).

Absence of alkaloid in some members of the group of Spondias was also reported by Gupta \& Moreira (2010) and Correia et al., (2006) when they are working with Spondias pinnata and $M$. indica. While, Silva et al. (2008), Asuquo et al. (2013) and Dantas et al. (2014) detected the presence of alkaloids, using the same methods of analysis when they were working with Umbu (Spondias tuberosa Arr. Cam.) and Caja (Spondias mombin). This shows that the secondary metabolism of various phytochemicals can differ from environmental differences inherent in the ecosystem, for the same family (Matos, 1997); this issue is relevant through standardization needs of medicinal plant raw materials aimed at the validation of medicinal plants used locally, control of existing herbal medicines.

In present study, presence of saponins was not observed and this fact was confirmed by the various researcher when they were working on the other species such as Spondias tuberosa Arr Cam (umbu), A. occidentale (Cashew) and M. indica (mango) of the same family (Silva et al., 2008; Bessa et al., 2013; Silva \& Almeida, 2013), although work done with Spondias mombin
(Asuquo et al., 2013), Myracrodruon urundeuva and Spondias pinnata, revealed the presence of saponins (Dantas et al., 2008).

Observed chemical compounds have hemolytic, antiinflammatory, antifungal, antibacterial, antimicrobial, antiparasitic, cytotoxic, antitumor and antiviral activities. The discrepancies in the results for alkaloids and saponins qualitative comparisons may be due to the variation in various factors such as soil, climate, the collection of material, temperature and chemicals (Cechinil \& Yunes, 1998).

The chemical constituents present in the extracts of Spondias studied may respond mainly by the biological activity which confirms a pharmacological value to this family, such as antioxidant, anti-infection activities, antibacterial, antifungal and anti-protozoan, anti-inflammatory and analgesic agents (Rocha et al., 2011).

\section{Conclusion}

The phytochemical analysis provides relevant information about the presence of secondary metabolites in plants so that it can reach the isolation of active principles in production of new herbal medicines. The data obtained can be concluded that the species showed good results for the tannins, flavonoids, steroids, terpenoids and not showing the presence of alkaloids and saponins, these analyzes indicated that the studied plant species has compounds that can be potentially active in biological models and pharmacological. Tests are required for the fractionation of crude extracts obtained from leaves to identify the 
active ingredients and perform bioassays to prove possible biological activity.

\section{References}

Asuquo OR, Fischer CE, Mesembe OE, Igiri AO, Ekom JI (2013) Comparative Study of aqueous and ethanolic leaf extracts of Spondias mombin on neurobehaviour in male rats. Journal of Pharmacy and Biological Sciences 5 :29- 35. DOI: http:// dx.doi.org/10.9790/3008-0522935

Bessa NG, Borges JCM, Beserra FP, Carvalho RHA, Pereira MAB, Fagundes R, Campos SL, Ribeiro LU, Quirino MS, Chagas Junior AF, Alves A (2013) A Prospecção fitoquímica preliminar de plantas nativas do cerrado de uso popular medicinal pela comunidade rural do assentamento vale verde -Tocantins. Revista Brasileira de Plantas Medicinais 15: 692-707. DOI: http://dx.doi.org/10.1590/S1516-05722013000500010.

Cechinel Filho V, Yunes RA (1998) Estratégias para a obtenção de compostos farmacologicamente ativos a partir de plantas medicinais: conceitos sobre modificação estrutural para otimização da atividade. Química Nova 21: 99-105. DOI: http://dx.doi.org/10.1590/S0100-40421998000100015.

Corrêa JCR, Salgado HRN (2011) Atividade inseticida das plantas e aplicações: revisão. Revista Brasileira de Plantas Medicinais 13: 500-506.

Correia SJ, David JP, David JM (2006) Metabólitos Secundários de Espécies de Anacardiaceae. Quimica Nova 29: 1287-1300.

Costa AF (2000) Farmacognosia Experimental, 3 ed. Lisboa: Fundação Caloust Gulbekian 3: 992.

Dantas BF, Correia JS, Marinho LB, Aragão CA (2008) Alterações bioquímicas durante a embebição de sementes de catingueira (Caesalpinia pyramidalis Tul.). Revista Brasileira de Sementes, Rio Grande do Sul 30: 221-227.

Dantas RS, Dias J, Albuquerque H, Cabral I, Medeiros A, Santos V (2014) Estudo Preliminar Fitoquímico E Da Atividade Analgésica Do Extrato Etanólico de Spondias mombin. BioFarm 10: $149-158$.

Forman L, Bridson D (1989) The herbarium handbook. Kew Great Britanic: Royal Botanic Gardens, Pp. 214.

Forzza RC (2012) Lista de Espécies da Flora do Brasil, 2012.
Available on http://floradobrasil.jbrj.gov.br/2012 access on: $10^{\text {th }}$ April, 2014.

Gupta VK, Moreira AC (2010) Antimicrobial activity of Spondias pinnata resin. Journal of Medicinal Plants Research 4: 1656-1661.

Haida KS, Parzianello L, Werner S, Garcia DR, Inácio CV (2007) Avaliação in vitro da atividade antimicrobiana de oito espécies de plantas medicinais. Arquivos de Ciências da Saúde da UNIPAR 11: 185-192. DOI: https://doi.org/10.25110/arqsaude.v11i3.2007.2037.

Macedo FM, Martins GT, Rodrigues CG, de Oliveira DA (2007) Triagem fitoquímica do Barbatimão Stryphnodendron adstringens (Mart.) Coville. Revista Brasileira de Biociências 5: 1166-1168.

Matos FJA (1997) Introdução à fitoquímica experimental. UFC Edições Pp. 44-46.

Missouri Botanical Garden - MOBOT (2012) Ciência Florestal, Santa Maria, 24 : 455-463. Available on http://www.tropicos.org access on $14^{\text {th }}$ April, 2014.

Rocha WS, Lopes RM, da Silva DB, Vieira RF, da Silva JP, Agostini-Costa TS (2011) Compostos fenólicos totais e taninos condensados em frutas nativas do cerrado. Revista Brasileira de Fruticultura 33: 1215-1221.

Silva GA, Brito NJN, Santos ECG, López JÁ, Almeida MG (2014) Gênero Spondias: aspectos botânicos, composição química e potencial farmacológico. BioFarm 10: 27-41.

Silva JG, Souza IA, Higino JS, Siqueira-Junior JP, Pereira JV, Pereira MSV (2007) Atividade antimicrobiana do extrato de Anacardium occidentale L. em amostras multiresistentes de Staphylococcus aureus. Revista Brasileira de Farmacognosia 17: 572-577.

Silva Junior JF, Almeida ER (2013) Collecting, ex situ conservation and characterization of caja'- umbuece (Spondias mombin x Spondias tuberosa) germplasm in Pernambuco State, Brazil. Genetic Resources and Crop Evolution 51: 343-349.

Silva ON, Chinalia LA, Paiva JGA (2008) Caracterização histoquímica dos folíolos de Spondias tuberosa Arruda (Anacardiaceae L.). Revista caatinga 21: 62-68.

Verdi LG, Brighente IMC, Pizzolatti MG (2005) Gênero Baccharis (asteraceae): aspectos químicos, econômicos e biológicos. Química Nova 28: 85-94. 